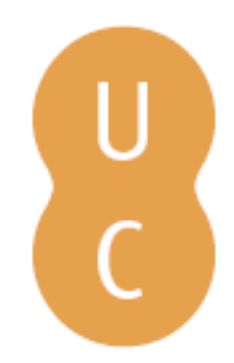

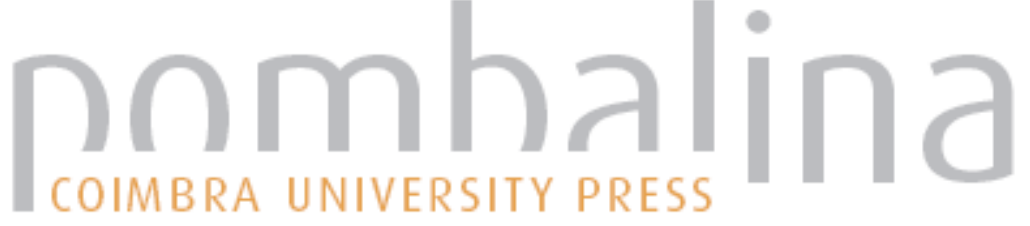

\section{Time perspective of older adults: research and clinical practice}

\author{
Autor(es): Kazakina, Elena
}

Publicado por: Imprensa da Universidade de Coimbra

URL

persistente: URI:http://hdl.handle.net/10316.2/38611

DOI: $\quad$ DOI:http://dx.doi.org/10.14195/978-989-26-0775-7_7

Accessed : $\quad$ 26-Apr-2023 11:54:20

A navegação consulta e descarregamento dos títulos inseridos nas Bibliotecas Digitais UC Digitalis, UC Pombalina e UC Impactum, pressupõem a aceitação plena e sem reservas dos Termos e Condições de Uso destas Bibliotecas Digitais, disponíveis em https://digitalis.uc.pt/pt-pt/termos.

Conforme exposto nos referidos Termos e Condições de Uso, o descarregamento de títulos de acesso restrito requer uma licença válida de autorização devendo o utilizador aceder ao(s) documento(s) a partir de um endereço de IP da instituição detentora da supramencionada licença.

Ao utilizador é apenas permitido o descarregamento para uso pessoal, pelo que o emprego do(s) título(s) descarregado(s) para outro fim, designadamente comercial, carece de autorização do respetivo autor ou editor da obra.

Na medida em que todas as obras da UC Digitalis se encontram protegidas pelo Código do Direito de Autor e Direitos Conexos e demais legislação aplicável, toda a cópia, parcial ou total, deste documento, nos casos em que é legalmente admitida, deverá conter ou fazer-se acompanhar por este aviso.

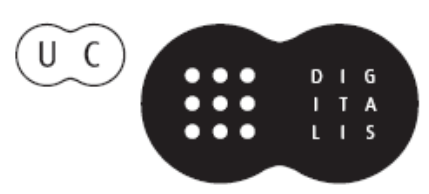




\section{INTERNATIONAL \\ STUDIES IN TIME \\ PERSPECTIVE}

MARIA PAULA PAIXÃO

JOSÉ TOMÁS DA SILVA

(COORD.)

VICTOR ORTUÑO

PEDRO CORDEIRO

(EDITORS)

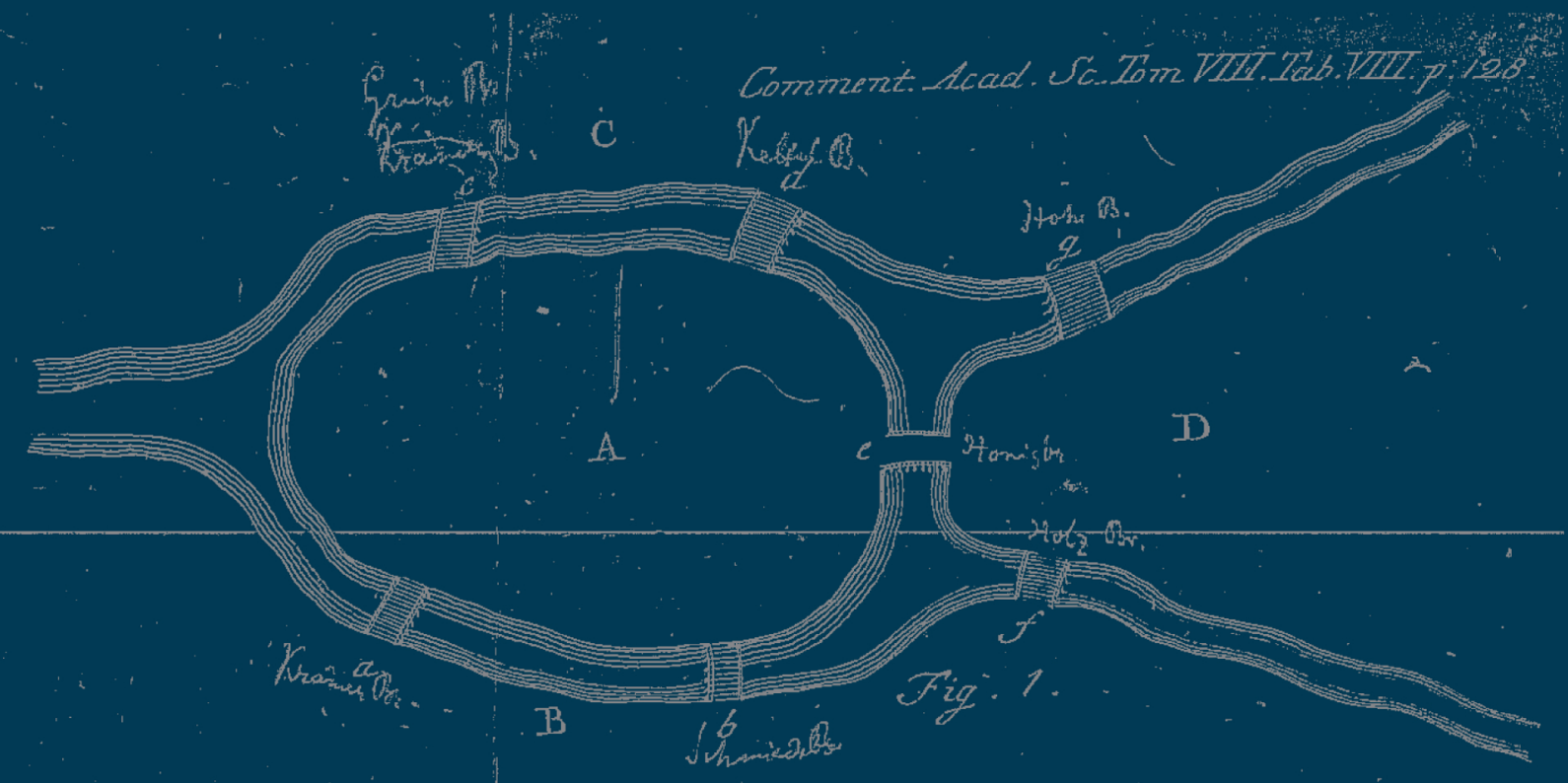

IMPRENSA DA

UNIVERSIDADE

DE COIMBRA

COIMBRA

UNIVERSITY

PRESS 
Chapter 7

Time Perspective of Older Adults: Research and Clinical Practice

\author{
Elena Kazakina \\ Independent practice, East Brunswick, New Jersey, USA \\ ekazakina@comcast.net
}

Aвstract: Time perspective was investigated in 103 women and men aged 65 to 91 in relation to their well-being, distress and attachment style. Unlike prior research that frequently reduced time perspective to a single time orientation (e.g., future), or to a single temporal dimension (e.g., extension - projection into the future or past), my study investigated all three time orientations, past, present and future and along multiple dimensions (density, emotional valence, extension, time continuity, and temporal balance). The findings revealed that positive functioning in late life was associated with several "healthy" components of time perspective: positive attitudes toward the present and past, a sense of connection among time orientations and a balanced perception of positive aspects of one's past, present, and future. Time perspective psychotherapy developed based on the concepts and findings of my research and the Zimbardo temporal model emphasizes the notion of balanced temporality in clinical work. The review of clinical strategies demonstrates how a time perspective approach can be integrated with cognitive-behavioral and psychodynamic interventions, enhancing the effectiveness of treatment. Clinical cases have demonstrated the alleviation of symptoms of psychological distress and enhancement of successful aging.

Keywords: older adults, time perspective psychotherapy, balanced temporality, successful aging.

\title{
Overview
}

Each research project has its own past, present and future. I left the former Soviet Union in 1989 before the Berlin Wall fell. I was heading into the future, leaving behind the past. In my professional life I did psychological research on actors' creativity and self-actualization. I did not know I would become a psychologist again. The experience of transition and multiple cultural adjustments compelled me to understand how people perceive time, the time of our lives. The most gripping question was whether positive adjustment may allow one to hold on to all three time orientations, past, present and future, rather than sacrifice one for another, with future orientation dominating the temporal perspective, as American culture seemed to require. Could the connection or continuity among time orientations be possible in people facing challenges of change?

Three years later, enrolled in a doctoral program and struggling to formulate the topic of my dissertation, I brought my interest to the attention of my academic advisor, Dr. Winthrop Adkins. He encouraged me to pursue it. My school, Columbia University Teachers College, had a tradition of using doctoral dissertations to examine complex and novel topics. Perhaps this approach honored the philosophy and spirit of its famous alumnae Carl Rogers and Rollo May. 
My passionate personal idea when embarking on the dissertation in the early nineties was that all three time orientations, past, present and future had to be respected in the American culture and society, to enhance depth and meaning of its cultural and public life. I believed that in order to obtain a deep and comprehensive understanding of individuals' time perspective, all three time frames had to be represented in research studies.

Time perspective literature of that period by and large focused either on one time orientation (most often the future) or on a single temporal dimension (e.g., extension of projection into the future or past). That is why I felt a personal commitment for each temporal orientation, past, present, and future, to be given a full, multidimensional representation in the personal experience of time. I was also curious to know how people who were characterized by future optimism saw their present and past, and in what way positive and negative reminiscences were connected with one's view of the future and present.

My basic idea - that I tested as a hypothesis - was that the balance of time orientations and their interconnectedness (concepts of temporal balance and temporal continuity), as well as their disruptions, could be more essential and perhaps sophisticated indicators and predictors of positive and negative aspects of individual functioning than time-related phenomena associated with only one particular time frame, such as positive future outlook.

My interest in older adults stemmed from the courses on adult development and aging I took at Columbia ${ }^{1}$. The experience of late life was shown to have a dramatic and touching streak that reminded me of my work with actors. Also, my interest in older Americans - whether in contacts on a subway or during my externships - pointed out a new path of professional direction. I felt a strange level of comfort and kinship with the older generation as though it represented something dear to me, something I left behind. The "Greatest Generation's" experience in World War II resonated with the history of my family in Russia during the war, the memory of which remained very close to our presentday collective consciousness. Also, aging appeared to be a great model for transition - not from country to country but from one developmental stage to another. The key element of transition - its inevitable losses and gains - became a dominant theme of my then present.

Working on my dissertation "Time perspective of older adults: relationship to attachment style, psychological well-being and psychological distress" helped me to integrate and balance my own past, present and future. My dissertation sponsor, Professor Elizabeth Midlarsky, not only guided me through the process but also suggested that I examine the relationship of temporal phenomena with a very important but little known variable, attachment style (capacity for close, trusting and enduring relationships). The study of this aspect of functioning in late life produced exciting results that resonate with new research about balanced time perspective and emotional intelligence (Stolarski, Bitner $\&$ Zimbardo, 2011). My interest in combining research and clinical insights brought me forward to this day, solidifying the continuity of my professional choices.

Now, the field of time perspective research is flourishing. It has endured a significant shift since the publication of influential work by Zimbardo and Boyd (1999). The authors offered a valid, reliable and comprehensive time perspective measure and a solid theory emphasizing the importance of balanced time perspective for individuals' optimal

${ }^{1}$ I would like to thank Nan Kramer, PhD, for sparking my interest in aging and for collegial support and friendship in my further career 
functioning. In fact, I felt that my approach was validated and was amazed by the similarities in our conceptualization of the importance of all three time frames, past, present and future in time perspective.

It is most gratifying to see that the balanced time perspective concept has found a strong following: the new interesting studies focus on more accurate measures of the balance of time orientations and its relationship with more sophisticated aspects of positive functioning (Boniwell, 2011; Drake, Dunkan, Sutherland, Abernethy, \& Colette, 2008; Zhang, Howell, \& Stolarski, 2012).

However, older adults are rarely the object of time perspective research and, particularly, of balanced time perspective studies. The most notable exception among the few inquiries that have included older adults is the recent publication by Desmyter and De Raedt (2012). With the world population aging and living longer than ever before, it seems absolutely essential for psychologists to address the themes of time and temporality that are critical to discussions of aging (Hendricks, 2001).

Further, in this article, I will describe the theoretical background and major findings of my original study. Then I will demonstrate how my research informed my clinical practice: I will delineate the notion of balanced temporality and how it was enriched by the work of Zimbardo and colleagues. Also, I will explain the temporal focus of my clinical practice, examining cognitive-behavioral and psychodynamic interventions within the context of time perspective counseling and psychotherapy. The case discussed will demonstrate a reduction of symptoms and enhancement of successful aging in clinical work with older adults.

\section{RESEARCH}

\section{Theoretical Background}

My doctoral study was designed to determine the time perspective of older adults and its relationship to their attachment style, psychological well-being and distress.

The focus of the study was on the construct, "time perspective," which presents an individual's "characteristic way of relating to the psychological concepts of past, present and future" (Block, 1989, p. 65). Time perspective was viewed as a facet of the subjective experience of "lived time" understood as personally meaningful time of one's life (Minkowski, 1933/1970, Gorman \& Wessman, 1977).

One of the central theoretical concepts upon which this study was based and which continues to illuminate my clinical work is the concept of temporal integration. It is understood as "the integrity of time based on the inner correlation and coexistence of its parts" (Kummel, as cited in Cottle, 1976, p. 15). Lewin's (1942/1997) understanding of time perspective, as "the totality of the individual's views of his psychological future and his psychological past existing at a given time" (p. 222) also underlines time perspective's integral character.

However, research - especially prior to the groundbreaking publication of Zimbardo and Boyd in 1999 - has rarely focused on time perspective as combining all three time referents: past, present, and future. Previous studies by and large selected one time orientation for investigation (see literature review in Kazakina, 1999). Most frequently 
(regardless of the age group being studied), the focus was on the future orientation, which in Western and particularly American society reflects the cultural value of progress and achievement (Gorman \& Wessman, 1977; Kastenbaum, 1964). Another limitation involved a single measure approach to time perspective; i.e., focusing on one temporal dimension, for example, on extension - projection into the future or past.

In my study an investigation of past, present, and future orientations was conducted in one population and along multiple dimensions. A multiple dimension approach was strongly recommended in the literature (Jones, 1994), but it was rarely applied in actual studies (Carr, 1985; Kastenbaum, 1982; Rappaport, Enrich, \& Wilson, 1985). Each time orientation was examined along the dimensions of density, emotional valence, and extension (i.e., number of experiences, thoughts and feelings allocated to each temporal frame, their emotional tone, and length of period over which they are projected into the past or future).

In addition, my study distinguished two rarely examined variables -- temporal continuity and temporal balance. Both characterized time perspective as a whole, expressing interconnectedness and coexistence of the three temporal regions, also known as temporal integration.

Temporal continuity was understood as a person's tendency to perceive his or her past, present, and future as meaningfully connected. Literature review pointed out only a few studies (samples of younger adults) where temporal continuity presented an object of investigation. Then, it was found to be positively correlated with intelligence, achievement needs (Cottle, 1976), ego strength, parameters of self-actualization (Getsinger, 1975), purpose in life and positive evaluation of the present (Robertson, 1978), creativity and positive perception of time (Yonge, 1975). However, existing research revealed a striking paucity of empirical data on temporal continuity in old age.

Temporal balance was conceptualized in my study as the relative equilibrium of thoughts and feelings allocated to recollecting the past, experiencing the present, and dreaming and planning for the future.

Traditionally, a dominant focus on futurity was regarded as an indicator of adaptation and mental health (Kahana \& Kahana, 1983; Schonfield, 1973; Seginer, 2009), but the findings in this area were inconsistent (Boniwell, 2011; Cameron et al., 1977-78).

By contrast, my study emphasized the importance of balanced temporal orientations for psychological health based on conceptualization of the "open mind" (Rokeach, 1960), "healthy" time line (Rappaport, 1990), time competence (Shostrom, 1968), and "openness" of an individual to past, present and future (Nuttin, 1985, Rappaport, 1990).

One goal of this inquiry was to provide a comprehensive, i.e., multidimensional picture of time perspective of older adults. Another goal was to determine the relationship of the time perspective of older adults to their attachment security (capacity for close enduring relationships), psychological well-being, and distress. Although the importance of wellbeing and distress is well-documented in the literature (Birren, Sloane, \& Cohen, 1992; Ryff, 1989), their relationship to all three time orientations in old age has been insufficiently explored. Attachment relationships in later life only recently have been gaining attention in the research (Antonucci, 1994; Browne \& Shlosberg, 2006). Issues of connections between attachment security and time perspective implied in theory (Erikson, 1985) had hardly been investigated among younger adults or older adults, thereby presenting a new area for exploration in this study. 
On the basis of the literature review on time perspective dimensions and their correlates in the area of personality functioning, it was postulated that older adults whose time perspective was characterized by greater continuity among time zones, greater balance of time orientations (on the dimensions of density, emotional valence and extensions), higher positive emotional valence of time zones, and greater extensions, would be securely attached and would report higher well-being and lower distress.

\section{Method}

\section{Sample}

Participants of this predominantly Caucasian sample were 103 community-dwelling older adults residing in the New York metropolitan area. Their age range was from 65 to 91 years. It included 78 females and 25 males. Participants were volunteers recruited from senior citizens' centers, housing complexes and community organizations.

\section{Procedure}

Data were collected during a one-time interview session that lasted an average of two hours.

All psychological instruments were administered in interview format, although they are paper-and-pencil questionnaires that are usually self-administered. This approach presents an effective method of data collection with older respondents (Midlarsky, 1992; Reed, 1991).

\section{Measures}

Study variables and measures are listed in Table 1 . Here I would like to point out a few aspects of the use of the measures of Temporal Continuity and Temporal Balance.

Temporal continuity, ability to see past, present and future as meaningfully connected, was assessed by the Time Competence Scale, one of the two major subscales of the Personal Orientation Inventory (POI) (Shostrom, 1968). POI was designed to assess an individual's level of self-actualization. Time Competence Scale measuring an individual's ability to tie the personal past and the future to the present (Shostrom, 1968) was very infrequently correlated with the time perspective dimensions (e.g., Getsinger 1975). Also, older individuals seemed to be neglected in self-actualization research: both the Time Competence Scale and the whole inventory, POI, were rarely used in later life. The relatively recent implementation of the Time Competence Scale (Boyd-Wilson, Walkey, \& McClure, 2002) included again only young adults and used the scale as a measure of the dominant present rather than the connectedness among past, present, and future. An important reminder is that the original conceptualization of time competence (Shostrom, 1968) indeed highlighted the importance of the present, but the essence of "a Time Competent orientation" according to Shostrom (1968), was represented in the POI statement "For me, past, present and future is in meaningful continuity" (p.19). 
Temporal balance has been rarely operationally defined or directly measured, and its operational definitions continue to challenge researchers of balanced time perspective (e.g., Zhang, Howell, \& Stolarski, 2012). One of the goals of this study was to measure the degree of balance of time orientations for each individual and the total sample of older adults. The notion was that a more even allocation of one's experiences and feelings over the three time periods (i.e., low variability of past, present, and future scores) was associated with a higher balance of orientations. The balance of time orientations was represented by the indices of balance, calculated on the basis of temporal dimensions, density, emotional valence, extension, and thoughts focus. Each index of balance was calculated as a standard deviation of past, present, and future scores from their mean.

Table 1 - List of Variables and Measures by Categories

\begin{tabular}{|c|c|}
\hline $\begin{array}{l}\text { TIME PERSPECTIVE VARIABLES } \\
\text { ("Predictors") }\end{array}$ & Measures \\
\hline & The Time Reference Inventory (Roos \& Albers, 1965) \\
\hline Density (Past, Present, Future) & Number of items referred to a time zone \\
\hline \multicolumn{2}{|l|}{ Emotional Valence (Past, Present, Future) } \\
\hline Positive & Number of positive items referred to a time zone \\
\hline Negative & Number of negative items referred to a time zone \\
\hline Neutral & Number of neutral items referred to a time zone \\
\hline Extension (Past, Future) & $\begin{array}{l}\text { Averaged differences between respondents' chronologi- } \\
\text { cal age and their estimated age on the items selected } \\
\text { (a) as past-related and } \\
\text { (b) as future-related. }\end{array}$ \\
\hline \multicolumn{2}{|l|}{ Emotional Valence: Positive } \\
\hline Positive Time Attitude (Past, Present, Future) & The Time Attitude Scale (Nuttin, 1985) \\
\hline \multicolumn{2}{|l|}{ Time Continuity } \\
\hline Time Competence & $\begin{array}{l}\text { The Time Competence Scale (Personal Orientation } \\
\text { Inventory) (Shostrom, 1968) }\end{array}$ \\
\hline \multicolumn{2}{|l|}{ Temporal Balance } \\
\hline Temporal Balance of Focus Index & $\begin{array}{l}\text { The Temporal Balance Scale (Adapted Kuhlen \& } \\
\text { Monge, 1968) }\end{array}$ \\
\hline Balance of Density & The Time Reference Inventory (TRI) \\
\hline Balance of Emotional Valence & TRI and Time Attitude Scale \\
\hline \multirow[t]{2}{*}{ Balance of Extension } & The Time Reference Inventory \\
\hline & $\begin{array}{l}\text { Indices of temporal balance based on the measures of } \\
\text { density, emotional valence and extension calculated as } \\
\text { a standard deviation }\end{array}$ \\
\hline
\end{tabular}




\begin{tabular}{|c|l|}
\hline \multicolumn{1}{|c|}{$\begin{array}{c}\text { OTHER STUDY VARIABLES } \\
\text { ("Criterion") }\end{array}$} & \\
\hline Attachment Style & The Revised Adult Attachment Scale (Collins, 1995) \\
\hline Psychological Well-Being & The Affect Balance Scale (Bradburn, 1969) \\
\hline Affect Balance & The Life Satisfaction Index - Z (Wood et al., 1969) \\
\hline Life Satisfaction & $\begin{array}{l}\text { The Center for Epidemiological Studies Depression } \\
\text { Scale (Hertzog et al. 1990) }\end{array}$ \\
\hline Psychological Distress & Brief Symptom Inventory (Derogatis, 1993) \\
\hline Depression &
\end{tabular}

\section{Study Design and Statistical Analysis}

The design of the study was correlational. The associations of time perspective variables and measures of attachment style, well-being, and distress were assessed in multivariate analyses where the impact of demographic factors was controlled. On the basis of the literature review, time perspective dimensions were conceptualized as predictor variables, whereas attachment, well-being, and distress were designated as criterion variables.

\section{Major Findings}

Findings that are most relevant to the current research on time perspective and clinical practice are reported in this section.

\section{Time perspective and attachment security}

My study documented that older adults who were securely attached (those with close and trusting interpersonal connections) had the more balanced time orientations and experienced a greater sense of connection among personal past, present, and future. Thus attachment security was most closely related to the essential aspects of time perspective: balance and continuity of past, present and future. In this study these variables were found to be independent from each other, presenting two distinct manifestations of temporal integration.

It should be noted that only one type of temporal balance contributed to attachment security: the balance of positive experiences, thoughts and feelings across time regions (emotional valence measure derived from TRI, Time Reference Inventory, Roos \& Albers, 1965).

The association between a disturbed time perspective and problems with close relationships is illustrated in the case of a 74-year old widow with an insecure attachment style who complained about being surrounded by the "wrong and shallow people." She 
referred all statements (TRI) describing positive experiences and feelings to the past and experienced the present as an island unrelated to the past and future.

Another finding related to the role of education in attachment security. Securely attached older adults were found to have more years of schooling. It should be added that the more educated elders in this study also had greater time continuity, i.e., a higher score on the Time Competence Scale. Time competence or ability to use one's past in understanding the present and planning for the future is an aspect of self-actualization (Shostrom, 1968).

Thus, the empirical findings obtained in my study pointed out connections among rarely examined phenomena of late life: secure attachment, balance and continuity of time perspective, and level of educational attainment.

The empirical link between older adults' time perspective variables of continuity and balance, and attachment security, may be derived from their common root in the quality of mothering, "When a child is hungry, it cries and extends its arms towards its nurse: this is the seed of the idea of future" (Guyau, cited in Droit \& Pouthas, 1992, p. 45). Indeed, connection between secure attachment in children and early development of time concepts was noticed in the literature (Fraisse, 1975;Gorman \& Wessman, 1977; Melges, 1982). However, it was unclear whether and how these tendencies persisted and interacted in adulthood and aging.

My interpretation of these results emphasized that attachment security provided a growing individual with a secure base (Bowlby, 1967) from which it was possible to explore the world, eventually pursuing higher goals in self-actualization (Maslow, 1970). The manifestations of secure style, such as confidence, positive attitude towards self and others (Antonucci, 1994), higher educational attainment and temporal continuity - the ability to see meaningful connections in one's past, present and future - seem to express different aspects of positive functioning of individuals.

Current research has not yet addressed the issues of attachment phenomena and time perspective. However, a recent innovative theoretical and empirical link establishing a positive connection between balanced time perspective and emotional intelligence (Stolarski et al., 2011) resonates with my results. The connections between emotional intelligence and secure attachment pointed out in the literature (Lopez, 2011) may enable further research which brings these phenomena into the studies of time perspective. From my point of view, such inquiry may deepen our understanding of positive temporality and strengthen "the scaffolding supporting optimal human growth and development" (Lopez, 2011, 406).

\section{Time perspective and psychological well-being}

The analysis of the relationship of time perspective variables to psychological wellbeing revealed the importance of positive attitudes of older adults toward their present, and their past as measured by Nuttin's (1985) adjectives scales (T.A.S.).

The supplemental multivariate analysis revealed that the strongest predictor of life satisfaction was positive present attitude followed by positive past (Kazakina, 1999, p.206). Positive present was also the strongest predictor of affect balance, another measure of psychological well-being. 
The importance of positive feelings about one's present and one's past for life satisfaction documented in this study was consistent with Erikson's (1985) stage of ego integrity, which emphasizes acceptance of one's present as well as one's past life with its triumphs and disappointments. Also, one of the aspects of well-being postulated by Ryff (1989) was self-acceptance, which involves positive attitudes towards current self as well as positive feelings about past life. In addition, empirical findings within socioemotional selectivity theory (Carstensen, Isaakowitz, \& Charles,1999) pointed to the increasing meaning and satisfaction that older adults experience in the present due to their awareness of time left in life, which restructures personal choices.

\section{Time perspective and psychological distress}

The main time perspective variables contributing to the psychological distress were negative feelings about the present, and an imbalance of positive experiences, thoughts and feelings across time zones.

Psychological distress was conceptualized in this study as a broad range of negative affect, including depression and distressing psychological symptoms (e.g., anxiety). Depression was measured by the CES-Depression Scale (Radloff, 1977) and global index of distress obtained from the Brief Symptom Inventory (Derogatis, 1993).

The findings showed that depression was most related to negative emotional valence of present orientation, followed by imbalance of positive experiences over the three time zones. Global distress was exclusively related to the imbalance of positive experiences across past, present and future. Those older adults who failed to find positivity in each temporal orientation were at risk of heightened feeling of psychological distress.

\section{Clinical Practice}

\section{The Notion of Balanced Temporality}

The theory and findings of my study conducted in the late 90s laid the foundation of the time perspective approach in counseling and psychotherapy that I have been applying for more than 13 years. My clinical work incorporated a conceptual framework of time competence and self-actualization (Maslow, 1970; Shostrom, 1968). It was also informed by Temporally Oriented Psychotherapy (Rappaport, 1990) and later by the seminal contribution of Philip Zimbardo and colleagues to time perspective theory and research (Zimbardo \& Boyd, 1999, Boniwell \& Zimbardo, 2004; Boniwell, 2011).

Balanced temporality was initially defined as a relatively balanced combination of past, present and future orientations in the individual's time perspective that was viewed as an essential part of the subjective experience of time (Kazakina, 1999). My approach was based on the conceptualization of the balance of temporal orientations necessary for temporal integration and psychological health (Rappaport, 1990; Shostrom, 1968).

I later extended this concept to include those aspects of time perspective that were found in my research to be the most relevant temporal correlates of positive functioning in late life. These "healthy" time perspective variables involved a specific type of temporal 
balance - a balance of positive experiences, thoughts and feelings that older adults referred to their past, present and future. Other dimensions included temporal continuity - a sense of connection among past, present and future, positive feelings about the present, and positive feelings about the past. I suggested that these aspects of temporal experience needed to be evaluated and enhanced in counseling and psychotherapy with older adults. Positive future is a part of this formulation but its role in late life has to be clarified further due to inconsistent findings.

Further development of the notion of balanced temporality incorporated Zimbardo and Boyd's (1999) dynamic understanding of "balanced time perspective" associated with positive functioning. The balance was viewed not only as a state but also as an ongoing process of balancing (emphasis added; Boniwell \& Zimbardo, 2004). The key part of this process is the flexible switching of temporal frames among past, future and present, depending on situational demands and personal resources to avoid temporal bias (overuse or underuse of any particular time orientation) (Zimbardo \& Boyd, 1999, p. 1272).

\section{Time Perspective Psychotherapy}

Time perspective therapy can be defined as psychotherapy in which temporal focus - awareness of psychological concepts of past, present and future, and their interaction underlies clinical interventions. The notion of balanced temporality is critical for setting clinical goals in treatment and psychotherapy. "If psychotherapy may be considered to be a process of value re-orientation for the patient, a significant step can be made in helping the client to realize the proper balance between past, present, and future orientations." (Shostrom, 1968, p.19).

However, based on my findings, I specify the temporal balance as a balance of the positive experiences across temporal regions, past, present and future (Kazakina, 1999). It is also important to emphasize that in the course of treatment I use temporal balance "as a yardstick of health in trying to ascertain the relative progress of a given patient" (Rappaport, 1990, p.189).

The first step for clinicians has to include evaluation of their own cultural and personal values about the concepts of past, present and future. Are there any implicit "favorites" or, as Gorman \& Wessman (1977) noted, "good guys versus bad guys?" Thomas Jefferson wrote once that he liked dreams of the future more than the memories of the past. This view may have been forever embedded in American cultural tradition. However, the basic attitude that followed from my study was based on respect for each temporal region and the enhancement of its balanced participation in an individual's functioning.

Another important step is to gain awareness of how we view the temporality of older adults. Are there any preconceptions and stereotypes about the experience of time in old age, such as "the elderly live only by their memories" or "old people have no future"?

Multidimensional approach to time perspective applied in my study has become a part of my clinical work, both in the evaluation phase and as treatment unfolds. It means that I have to understand how patients think and feel about each period of their lives - past, present, and future - and about their connections or disconnections. To what extent is each time period full or empty? What is the emotional tone associated with different aspects of each zone? How far in both directions - past and future - can a person see? What is the 
relative importance of past, present, and future for each individual? Can older clients find positive experiences in each temporal region in a relatively even fashion? If past, present, and future are split or disconnected, if one temporal zone "outweighs" another, or if one zone is excluded from an individual's perspective, this may signal a problem which needs to be dealt with in psychotherapy. "Problems" in time perspective could be triggered by various developmental issues of late life, such as declining health, widowhood, death of friends, or a required change of place of residence.

\section{Chinical Case}

The highlights of the psychotherapy case demonstrate the temporal focus of my clinical approach and how it is integrated with cognitive-behavioral and psychodynamic interventions.

Mrs. Smith (not her real name) is an 82-year-old Caucasian retired professional woman, a widow for 16 years who was looking for psychological services for the first time in her life. She reported anxiety, worry about her health, depression, and painful tension in the neck area. These symptoms were precipitated by the death of two of her close friends due to relatively sudden and serious illness. She experienced her present as purposeless, empty and lonely. Her spontaneous comments related to the recent past, with no references to the future.

An initial assessment registered her disconnected time orientations, negative feelings in the present, and exclusion of the future from her present psychological field. A strong therapeutic alliance was instrumental in creating first experiences of a positive present in which the patient felt connected and understood. The present became the focus of the clinical interventions.

I chose cognitive-behavioral strategies to help Mrs. Smith identify her automatic thoughts triggering depression, and also to help her master relaxation techniques to alleviate muscle tension and anxiety. Mrs. Smith's discussion of her tension pain elucidated her important insight. She realized that her pain subsided during a telephone conversation in which she gave professional advice and mentoring to her younger colleague.

Then, we shifted the focus to the past by discussing her successful work history. It allowed Mrs. Smith to discern her strengths and start making plans about resuming her important social connections, as well as consider meaningful volunteer work in the near future. This intervention may give an example of enhancing a patient's time continuity and sense of connections between her past, present and future. However, in order to solidify the growing temporal integration and address the issue of depression and loss, the patient's powerful emotional reaction to the death of her friends had to be revisited.

Psychodynamic intervention focused on the patient's strong emotional response, "being threatened" because of the death of her friends. Her associations took her to a similar emotion in the distant past. Mrs. Smith's mother died when she was 2 years old. She recalled that when she was about 10 , her caretaker wanted to send her to distant relatives. The patient recalled feeling severely threatened by this. This recollection brought to light the nature of the patient's vulnerability and distress, helping her better understand her feelings in the present. Although my initial hypothesis for the patient's symptoms was "death anxiety," therapy revealed that her symptoms were triggered by fears of abandonment and loneliness in the present rather than of death, in the future. 
One aspect of therapy is of importance here: the creation of patient and clinician "common psychotherapy past." Mrs. Smith expressed fascination with a therapy process that instigated her "mental connections" as well as with the effect of her insights on her mood relieving her depression and anxiety. When comparing her initial severe distress to her significant improvement, Mrs. Smith pointed out "the road she traveled" and recognized the impact of therapy as "returning back to herself."

This recent positive past helped enhance the patient's self-esteem. She became more responsive to my "new round" of refocusing her on the present. The importance of Mrs. Smith's current close relationships was continuously emphasized in sessions and her present became gradually populated with resumed warm interpersonal connections (with step-children, neighbors, churchgoers and former colleagues). The treatment enhanced her attachment security. The emerging "hedonistic present" (Zimbardo \& Boyd, 1999, 2008) surfaced in Mrs. Smith's playful and humorous comments. One day she shared a compliment she received: she was greeted as "a cover girl" in the gym, where she renewed her membership.

Once her positive present was reinforced, shifting to the other time zones, past and future, became more fluid. She spoke about positive aspects of her past including her marriage and raising her stepchildren. She enrolled in a computer class "to become a better volunteer" during upcoming presidential elections. It turned out that Mrs. Smith had been a "political junkie" all her life. The assessment of progress reached in treatment pointed to the increased integration of positive experiences across past, present and future. This is a "healthy" aspect of time perspective positively associated with attachment security and negatively connected to psychological distress (Kazakina, 1999).

It should be noted that the goals of symptom reduction and enhancement of positive functioning are often theoretically separated (Jorgensen \& Nafstad, 2004). However, in clinical practice they can be intertwined. While patients are overcoming symptoms of immediate distress, they acquire growing sense of efficacy, and connection with others, leading further in treatment to their greater vitality, self-actualization and overall engagement with life. Engagement with life, one of the key features of successful aging (Rowe \& Kahn, 1998), is viewed as essential for older adults "continuing" their "valued personal activities" (Williamson \& Christie, 2011, p.168). To recreate this continuity when it is disrupted is one of the goals of time perspective therapy. This goal can be accomplished only when a person's ability to keep in mind past, present and future (Kastenbaum, 1965) is restored.

I view temporal flexibility - ability to switch from one temporal frame to another (Boniwell \& Zimbardo, 2004) not only as a goal for the patient to acquire but also as a tool for the clinician to use. Keeping in mind a patient's past, present and future while moving swiftly to the time orientation in need of immediate attention, and choosing the most appropriate clinical intervention, is at the core of my time perspective focused therapeutic approach.

\section{Conclusion}

This article focused on research and clinical practice with older adults, who are often underrepresented in the time perspective studies despite their dramatically growing numbers and the urgent need to comprehend the meaning of old age in the global economy (Carstensen, \& Fried, 2012). 
I have shown how my professional decisions have been affected by the need to establish time continuity, a sense of connection among personal past, present and future.

The goal of my research was to determine how older adults viewed their past, present, and future and how their time perspective related to their attachment security, well-being, and distress. In contrast to previous studies, which mostly searched for the predominant temporal orientation of an individual and often neglected the less salient time zones, or which emphasized the role of the future, I examined all three time orientations along multiple dimensions and determined the relative significance and balance of past, present, and future in the time perspective of older adults.

The study highlighted two global time perspective variables, time continuity and temporal balance; they seem to reflect distinct aspects of temporal integration, understood as the human capacity to extend beyond the present moment and to make connections among time regions (Melges, 1982).

The findings established the "healthy" components of the time perspective of older adults associated with their positive functioning: positive attitudes to present and past; sense of connection among time orientations; relatively balanced perception of positive aspects of past, present, and future. This implies that all three time regions can be available to older individuals, and thus their functioning becomes enriched by the recollected past, the evaluated present, and the anticipated future. In this case, positive aspects of past, present, and future are available or accessible (Jones, 1994) to older individuals. This appears to be a "fully-functioning" time perspective in old age.

My inquiry also extended time perspective research to the area of attachment security in old age, establishing little known connections among essential aspects of late life-the subjective experience of time and the capacity for trusting, enduring relationships. The role of continuity and balance in older adults' perception of their past, present and future in their attachment security, and potential impact of these phenomena on self-actualization was highlighted.

This chapter presented the notion of balanced temporality that became a theoretical framework for my approach in time perspective psychotherapy with older adults. I extended the concept of balanced time perspective (Zimbardo \& Boyd, 1999) to clinical practice and demonstrated that temporal flexibility can be viewed as a goal for patients to achieve and a skill for clinicians to use.

The case examination pointed out the temporal focus of clinical strategies and their interplay with cognitive-behavioral and psychodynamic interventions to increase effectiveness of treatment and enhancement of successful aging.

I believe the integration of time perspective research and clinical work is a promising development, which improves the quality of psychological services and helps the rapidly growing population of older adults to age successfully.

\section{REFERENCES}

Antonucci, T. C. (1994). Attachment in adulthood and aging. In M. B. Sperling \& W. B. Berman (Eds.), Attachment in adults (pp. 256 -272). New York: The Guilford Press.

Birren, J. E., Sloane, R. B., \& Cohen, G. D. (Eds.). (1992). Handbook of mental health and aging (2nd ed.). San Diego: Academic Press. 
BLock, R. A. (1989). A contextualistic view of time and mind. In J. T. Fraser (Ed.), Time and mind: Interdisciplinary issues. The study of time VI (pp. 61-79). Madison, CT: International Universities Press.

Boniwell, I. (2011). Perspectives on time. In S. J. Lopez \& C. R. Snyder (Eds.), Oxford handbook of positive psychology (2nd ed., pp.295 - 302). New York: Oxford University Press.

Boniwell, I., \& Zimbardo, P. G. (2004). Balancing time perspective in pursuit of optimal functioning. In P. A. Liney \& S. Joseph (Eds.), Positive psychology in practice (pp. 165-178). Hoboken, NJ: Wiley.

Bowlby, J. (1967). Maternal care and mental health [Second printing]. New York: Schocken Books. Boyd-Wilson, B.M., Walkey, F.H., \& McClure, J. (2002). Present and correct: We kid ourselves less when we live in the moment. Personality and individual differences, 33, 691-702.

Bradburn, N. M. (1969). Structure of psychological well-being. Chicago: Aldine Atherton.

Browne, C.J., \& Shlosberg, E. (2006). Attachment theory, ageing and dementia: A review of literature. Ageing and Mental Health, 10 (2), 134-142.

Cameron, P., Desai, K. G., Bahador, D., \& Dremel, G. (1977-78). Temporality across the lifespan. International Journal of Aging and Human Development, 8(3), 229-259.

CARR, M. A. (1985). The effects of aging and depression on time perspective in women. Unpublished doctoral dissertation, Columbia University.

Carstensen, L. L., Isaakowitz, D. M., \& Charles, S. T. (1999). Taking time seriously. American Psychologist, 54 (3), $165-181$.

Carstensen, L. L, \& L. P. Fried. (2012).The meaning of old age. In Global population ageing: Peril or promise? (pp. 15-17). World Economic Forum.

Collins, N. L., (1995). Revised Adult Attachment Scale. (Available from the author, Department of Psychology, SUNY, Buffalo, New York 14260-4110.

Cottle, T. J. (1976). Perceiving time. New York: Wiley.

Derogatis, L. R. (1993). Brief Symptom Inventory (BSI). Administration, scoring, and procedures manual (3rd ed.). Minneapolis: National Computers Systems.

Desmyter, F., De Raedt, R. (2012).The relationship between time perspective and subjective wellbeing of older adults. Psychologica Belgica, 52 (1), 19-38.

Drake, L., Dunkan, E., Sutherland, F., Abernethy, C., \& Colette, H. (2008). Time perspective and correlates of well-being. Time and Society, 17 (1), 47-67.

Droit, S., \& Pouthas, V. (1992). Changes in temporal regulation of behavior in young children: From action to representation. In F. Macar, V. Pouthas, \& Friedman, W. J. (Eds.), Time, action and cognition (pp. 45-53). Boston: Kluver Academic Publishers.

Erikson, E. H. (1985). Childhood and society (35th ed.). New York: Norton.

Fraisse, P. (1975). The psychology of time (J. Leith, Trans.). Westport, CT: Greenwood Press. (Reprinted from the edition published 1963, New York: Harper \& Row).

Getsinger, S. H. (1975). Temporal relatedness: Personality and behavioral correlates. Journal of Personality Assessment, 39(4), 405-408.

Gorman, B.S., \& Wessman, A. E. (1977). Images, values, and concepts of time in psychological research. In B. S. Gorman, \& A. E. Wessman (Eds.), The personal experience of time (pp. 217263). New York: Plenum Press.

Hendricks, J. (2001). It's about time. In S. H., \& R. C., Atchley (Eds.), Aging and the meaning of time (pp 21-50). New York: Springer. 
Hertzog, C., Van Alstine, J., Usala, P. D., \& Hultsch, D. F. (1990). Measurement properties of the Center for Epidemiological Studies Depression Scale (CES-D) in older populations. Psychological Assessment, 2, 64-72.

Jones, J. M. (1994). An exploration of temporality in human behavior. In R. C. Schank \& E. Langer (Eds.), Beliefs, reasoning and decision making (pp. 389-411). Hillsdale, NJ: Lawrence Erlbaum.

Jorgensen, I.S., \& Nafstad, H.E. (2004). Positive psychology: Historical. Philosophical, and epistemological perspectives. In P. A. Liney \& S. Joseph (Eds.), Positive psychology in practice (pp. 15- 34 ). Hoboken, NJ: Wiley.

Kahana, E., \& Kahana, B. (1983). Environmental continuity, futurity and adaptation of the aged. In G. D. Rowles \& R. J. Ohta (Eds.), Aging and milieu (pp. 205-228). New York: Academic Press.

Kastenbaum, R. (1964). The crisis of explanation. In R. Kastenbaum (Ed.), New thoughts of old age (pp. 316-323). New York: Springer.

Kastenbaum, R. (1965). The direction of time perspective: The influence of affective set. The Journal of General Psychology, 73, 189-201.

Kastenbaum, R. (1982). Time course and time perspective in later life. Annual Review of Gerontology and Geriatrics, 3, 80-101.

KaZAKInA, E. (1999).Time perspective of older adults: Relationships to attachment style, psychological well-being and psychological distress. Unpublished doctoral dissertation, Columbia University.

Kuhlen, R., \& Monge, R. (1968). Correlates of estimated rate of time passage in the adult years. Journal of Gerontology, 23, 427-433.

Lewin, K. (1942/1997). Field theory and learning. In D. Cartwright (Ed.). Field theory in social science. Selected theoretical papers. In Resolving social conflicts. Field theory in social science. (pp. 212230). Washington, DC American Psychological Association (Original work published 1942).

Lopez, F.G. Adult attachment security: The relational scaffolding of positive psychology. In S. J. Lopez \& C. R. Snyder (Eds.), Oxford handbook of positive psychology (2nd ed., pp.405 - 415). New York: Oxford University Press.

Maslow, A. H. (1970) Motivation and personality (2nd ed.). New York: Harper \& Row.

Melges, F. T. (1982). Time and the inner future. New York: Wiley.

Midlarsky, E. (1992). Psychotherapy and counseling with older adults: Predictors and barriers to participation. Unpublished research proposal submitted to the AARR Andrus Foundation. Teachers College, Columbia University.

Minkowski, E. (1970). Lived time (N. Metzel, Trans.). Evanston, IL: Northwestern University Press. (Original work published 1933).

Nuttin, J. (1985). Future time perspective and motivation. Hillsdale, NJ: Lawrence Erlbaum.

Rappaport, H. (1990). Marking time. New York: Simon and Shuster.

Rappaport, H., Enrich, K., \& Wilson, A. (1985). Relation between ego identity and temporal perspective. Journal of Personality and Social Psychology, 48(6), 1609-1620.

Reed P.G. (1991). Self-transcendence and mental health in oldest-old adults. Nursing Research, 40(1), 5-11.

Robertson, S. A. (1978). Some personality correlates of time competence, temporal extension and temporal evaluation. Perceptual and Motor Skills, 46, 743-750.

Rokeach, M. (1960). The open and closed mind. New York: Basic Books.

Roos, P., \& Albers, R. (1965). Performance of alcoholics and normals on a measure of temporal orientation. Journal of Clinical Psychology, 21(1), 34-36.

Row, J., \& Kahn, R. L. (1998). Successful aging. New York: Pantheon Books. 
RyFF, C. D. (1989). Happiness is everything, or is it? Explorations on the meaning of psychological well-being. Journal of Personality and Social Psychology, 57(6), 1069-1081.

SCHONFIELd, D. (1973). Future commitments and successful aging. Journal of Gerontology, 28, 189$-196$.

SEgIner, R. (2009). Future orientation. New York: Springer.

Sнолтrom, E.L. (1968). EITS Manual for the Personal Orientation Inventory. Educational and Industrial Testing Service.

Stolarski, M., Bitner, J., \& Zimbardo, P. G., (2011) Time perspective, emotional intelligence and discounting of delayed awards. Time and Society, 20 (3), 346-363.

Williamson, G. M., \& Christie, J. (2011). Aging well in the 21st century: Challenges and opportunities. In S. J. Lopez \& C. R. Snyder (Eds.), Oxford handbook of positive psychology (2nd ed., pp. 165 - 169). New York: Oxford University Press.

Wood, V., Wylie, M. L., \& Sheafor, B. (1969). An analysis of a short self-report measure of life satisfaction: Correlation with rater judgment. Journal of Gerontology, 24, 465-469.

Yonge, G. D. (1975). Time experiences, self-actualizing values, and creativity. Journal of Personality Assessment, 39(6), 601-606.

Zhang, J.W., Howell, R .T., \& Stolarski, M. (2012). Comparing three methods to measure a balanced time perspective: The relationship between a balanced time perspective and subjective well-being. Journal of Happiness Studies. doi: 1007/s10902-012-9322-x.

Zimbardo, P. G., \& Boyd, J.N. (1999). Putting time in perspective: A valid, reliable individualdifferences metric. Journal of Personality and Social Psychology, 77, 1271-1288.

Zimbardo, P. G., \& Boyd, J.N. (2008). The time paradox. New York: Free Press. 